\title{
IbM TENUN AQILA DAN LUMINTU
}

\author{
Musyafa $^{1}$, Hadi Ismanto ${ }^{2}$ \\ Fakultas Ekonomi dan Bisnis, Universitas Islam Nahdlatul Ulama' Jepara \\ Email : ${ }^{1}$ musyafa@unisnu.ac.id, ${ }^{2}$ hadifeb@unisnu.ac.id
}

\begin{abstract}
Troso's weaving product as a heritage of Troso village ancestors has so far spread and expand rapidly to all parts of Indonesia and become one of the economic support of Jepara society in general and society of Troso village in particular. However, with the strategic role, there are still obstacles in its empowerment. As the problems faced by both partners are UMKM Aqila Weaving and UMKMLumintu. Devotion to the implementation of science and technology for this community wants to overcome the problems faced by both partners are aspects of management, production, and marketing. The solutions offered are as follows: 1). Preparation of administrative system, 2). Added non-machine loom (ATBM) with anchors, and 3). Providing online marketing facilities. The method of implementation is done by stages of administration and productivity improvement. With the expertise and expertise of the implementing team, this community service will succeed
\end{abstract}

Keywords: UMKM, Tenun Troso, Empowerment

\section{PENDAHULUAN}

\section{Analisis Situasi}

Kain tenun ikat Troso adalah kriya tenun Jepara tepatnya dari desa Troso kecamatan Pecangaan kabupaten Jepara. Berupa kain yang ditenun dari helaian benang pakandan benang lungsi yang sebelumnya diikat untuk membentuk motif tertentu dan dicelupkan ke dalam zat pewarna alami. Kain ikat Troso merupakan kain khas yang diproduksi oleh penduduk desa Troso yang diwariskan dari nenek moyang penduduk Troso. Sampai saat ini kain tenun ikat Troso telah berkembang menjadi sebuah industri rumah tangga yang menopang perekonomian desa Troso dengan pasar yang tersebar luas di berbagai daerah di Indonesia.

Alat tenun yang dipakai adalah alat tenun bukan mesin (ATBM). Hal ini karena kain ikat Troso merupakan susunan dari helaian benang pakan yang sebelumnya telah dibentuk motif dengan cara diikat dan diberi warna, sehingga untuk membuat kain ikat tukang tenun harus menyusun dan menata satu persatu helaian benang tersebut agar mendapat motif yang diinginkan.

Dalam pengabdian ini tim melakukan peningkatan daya saing (pemberdayaan, empowerment) terhadap 
UMKM tenun Troso khusus kepada UMKM Tenun Aqila dan Lumintu. Berikut merupakan deskripsi mengenai kedua mitra, sebagai berikut:

\section{UMKM TENUN AQILA}

UMKM Tenun Aqila merupakan usaha yang didirikan oleh Bapak Suharto pada tahun 2012. Usaha ini dimulai muncul dari minat Bapak Suharto sebagai pemilik untuk memproduksi sendiri kain tenun yang telah menjadi kegiatan industri rumah tangga di Desa Troso. Produk yang diproduksi mulai berdiri sampai sekarang adalah kain tenun motif dengan bahan baku CSM 80/2 dan CSM 64/2, dengan motif yang bervariasi dan berkembang setiap saat.

Kapasitas produksi UMKM Tenun Aqila kurang lebih 320 potong perbulan, dimana jumlah kain yang diproduksi tergantung dengan kondisi atau kemampuan dari tenaga kerja yang masih mengandalkan tenaga manusia. Jumlah tenaga kerja yang dimiliki diantaranya: 10 orang penenun, 2 orang sebagai pengikat pola, 1 orang sebagai pengeteng, 1 orang penyepol, 1 orang pewarna dan 1 orang penyekir. Kemampuan peningkatan kapasitas produksi masih terbatas karena keterbatasan investasi yang dimiliki oleh Bapak Suharto terutama pada penambahan mesin, hal ini terjadi karena masih dikelolanya sistem administrasi dan sistem akuntansi yang tidak jelas, pengelolaan keuangan masih menjadi satu dengan keuangan keluarga. Akibatnya tidak ada pemisahan antara kekayaan pribadi dengan kekayaan perusahaan yang menyebabkan Tenun Aqila tidak mengetahui secara pasti keuntungan dan kemampuan modal kerja perusahaan. Kemampuan produksi Tenun Aqila ini dapat disajikan pada tabel 1

Tabel 1. Kemampuan Produksi

\begin{tabular}{|c|c|c|}
\hline $\begin{array}{c}\text { Jumlah } \\
\text { Penenun } \\
\text { (orang) }\end{array}$ & $\begin{array}{c}\text { Minggu } \\
\text { ke }\end{array}$ & $\begin{array}{c}\text { Jumlah } \\
\text { (Potong) }\end{array}$ \\
\hline \multirow{2}{*}{10} & 1 & 100 \\
\cline { 2 - 3 } & 2 & 90 \\
\cline { 2 - 3 } & 3 & 95 \\
\cline { 2 - 3 } & 4 & 98 \\
\hline Total & 383 \\
\hline \multicolumn{2}{|l|}{ Rata-rata per minggu } & 95 \\
\hline
\end{tabular}

Sumber: Di olah dari Mitra

Aspek pemasaran pada Tenun Aqila menggunakan sistem titip pada tengkulak yang ada di desa Troso, 
hal ini menjadikan harga jual produk kain tenun ikat Tenun Aqila mengikuti kemampuan tengkulak yang mendistribusikan kainnya ke pengguna akhir atau tengkulak yang lebih besar di Bali ataupun di Jakarta.

\section{UMKM LUMINTU}

Tenun Lumintu merupakan usaha Tenun Ikat yang didirikan oleh Bapak Muhammad Habib pada tahun 2009. Produk yang diproduksi merupakan kain tenun motif dengan bahan baku CSM 80/2 dan CSM $64 / 2$, dengan motif yang bervariasi dan berkembang setiap saat. Kapasitas produksi tenun ikat Muhammad Habib kurang lebih 156 potong perminggu, dimana jumlah kain yang diproduksi tergantung dengan kondisi atau kemampuan dari tenaga kerja yang masih mengandalkan tenaga manusia. Jumlah tenaga kerja yang dimiliki diantaranya: 25 orang penenun, 5 orang sebagai pengikat pola, 1 orang sebagai pengeteng, 1 orang penyepol, 1 orang pewarna dan 1 orang penyekir. Kemampuan produksi mitra ini dapat disajikan pada tabel 2 .
Tabel 2. Kemampuan Produksi

\begin{tabular}{|c|c|c|}
\hline $\begin{array}{c}\text { Jumlah } \\
\text { Penenun } \\
\text { (orang) }\end{array}$ & $\begin{array}{c}\text { Minggu } \\
\text { ke }\end{array}$ & $\begin{array}{c}\text { Jumlah } \\
\text { (Potong) }\end{array}$ \\
\hline \multirow{2}{*}{25} & 1 & 150 \\
\cline { 2 - 3 } & 2 & 160 \\
\cline { 2 - 3 } & 4 & 155 \\
\hline Total & & 625 \\
\hline \multicolumn{2}{|l|}{ Rata-rata per minggu } & 156 \\
\hline
\end{tabular}

Sumber: Di olah dari Mitra

Kemampuan peningkatan kapasitas produksi masih terbatas karena keterbatasan investasi yang dimiliki oleh Bapak Muhammad Habib terutama pada penambahan mesin, hal ini terjadi karena masih dikelolanya sistem administrasi dan sistem akuntansi yang tidak jelas. Pengelolaan keuangan masih menjadi satu dengan keuangan keluarga, tidak ada pemisahan antara kekayaan pribadi dengan kekayaan perusahaan yang menyebabkan Tenun Lumintu tidak mengetahui secara pasti keuntungan dan kemampuan modal kerja perusahaan.

Aspek pemasaran pada Tenun Lumintu menggunakan sistem titip pada tengkulak yang ada di Desa Troso, selain itu pemilik juga 
menjual produknya yang telah di bentuk pakaian lewat toko yang ada di Jakarta. Sedangkan harga jual produk kain tenun ikat Tenun Lumintu mengikuti kemampuan tengkulak yang mendistribusikan kainnya ke pengguna akhir atau tengkulak yang lebih besar di Bali ataupun di Jakarta.

\section{Permasalahan Mitra}

Permasalahan yang ada kedua mitra Tenun Ikata Troso Tenun Aqila dan tenun Lumintu sebagaimana yang teridentifikasi tim pengusul adalah sebagai berikut:

1. Aspek produksi, saat ini alat yang digunakan masih menggunakan alat tenun bukan mesin (ATBM) yang hanya dapat digunakan untuk menghasilkan kain motif. Sehingga perlu adanya penambahan alat yang dapat mempercepat produksi kain

2. Aspek Manajemen, mitra belum memiliki sistem administrasi maupun sistem akuntansi. Sehingga belum dapat mengetahui secara tepat keuntungan usahanya, pemilik hanya memperkirakan keuntungannya.

3. Sistem pemasaran, mitra masih mengandalkan tengkulak yang ada di desa Troso, sehingga perlu adanya cara atau teknik pemasaran yang dapat menembus pasar nasional yang sangat terbuka.

\section{SOLUSI DAN TARGET \\ Solusi Yang Ditawarkan}

Solusi yang ditawarkan sesuai dengan permasalahan prioritas yang disepakati dengan mitra Tenun Aqila dan Tenun Lumintu adalah sebagai berikut:

1. Aspek Produksi, Solusi yang ditawarkan pada kedua mitra adalah dengan memberikan alat tenun bukan mesin (ATBM) dengan tambahan jangkar yang digunakan untuk mempercepat dalam proses produksi untuk menambah kapasitas produksi kain motif, dimana kain ini memiliki pangsa pasar yang cukup luas. Hal ini sesuai dengan pendapat dari Rahmana et al (2012) yang menyatakan bahwa industri pengolahan harus memiliki teknologi agar memperoleh prospek pengembangan pasar. Dengan tambahan teknologi tersebut diharapkan terjadi peningkatan kapasitas produksi dan peningkatan kualitas dari kain dengan motif yang semakin bervariasi. Kapasitas Produksi yang dihasilkan oleh ATBM Jangkar kurang lebih 90-100 potong per bulan, sedangkan kalau pakai ATBM biasa hanya dapat 
memproduksi kurang lebih 32-40 potong perbulan.

2. Aspek manajemen, solusi yang ditawarkan dengan menyusun sistem administrasi bagi Tenun Aqila dan Tenun Lumintu dengan memberikan pelatihan dan pendampingan dalam penyusunan administrasi yang berbasis excel. Hal ini sesuai dengan pendapat Jumingan dan Rosita (2012) dalam studinya menemukan sebagian besar pelaku usaha kecil dan menengah menyadari manfaat dari pembukuan dan hal ini bisa melalui kegiatan pelatihan.

3. Aspek pemasaran, solusi yang ditawarkan dengan memberikan fasilitas pemasaran on line, guna mendukung sistem pemasaran yang ada saat ini. Pemasaran on line dibutuhkan guna menjangkau pasar yang lebih luas. Sesuai dengan pendapat Nugraheni (2011) mengemukakan bahwa e-commerce merupakan salah satu metode yang baik bagi usaha kecil dan menengah dalam memasarkan produknya

\section{Target}

Setelah mengikuti program IbM, mitra Tenun Aqila dan Tenun Lumintu, diharapkan mampu:
1. Meningkatkan Produktivitas produksi sebesar 25\% dari jumlah tahun 2016

2. Dimilikinya sistem administrasi dan akuntansi di masing-masing Mitra

3. Dimilikinya jaringan pemasaran baru melalui e-commerce guna memperoleh pasar yang potensial karena dapat diakses oleh setiap orang dimanapun tempatnya yang mempunyai akses internet

\section{METODE PELAKSANAAN}

Pada metode pelaksanaan dijelaskan mengenai tahapan atau langkah-langkah dalam melaksanakan solusi yang ditawarkan dalam mengatasi permasalahan yang terdiri sebagai berikut:

\section{Metode Pendekatan}

Metode pendekatan yang digunakan untuk menyelesaikan persoalan supaya target luaran tercapai:

1. Mempersiapkan Kebutuhan Utama

Supaya pengabdian ini berjalan sesuai yang diharapkan maka langkah utama yang harus dilakukan adalah mempersiapkan kebutuhan utama meliputi pemilihan alat tenun yang baik, alat jangkar yang sesuai dengan spesifikasi, pembuatan bahan excel, bahan pelatihan excel sedehana, bahan pembuatan website, 
dan koordinasi dengan mitra mengenai nama webs

2. Penyuluhan/pelatihan

Pelatihan dapat dilakukan dengan cara ceramah, diskusi, curah pendapat, serta praktek kepada mitra. Hal ini penting dilakukan untuk memberikan pemahaman tentang arti pentingnya produktifitas suatu usaha, administrasi yang sistematis dan pemasaran melalui $e$ commerse.

3. Pendampingan

Hal ini dilakukan untuk
mendapatkan kepastian atau
penguatan implementasi konsep
yang sudah diberikan dalam
penyuluhan atau pelatihan.
Pendampingan dilakukan secara
terstruktur melalui pertemuan
sekaligus sebagai sarana tukar
pengalaman dan konsultasi.
Pendampingan secara intensif juga
dilakukan dengan melibatkan
mahasiswa sebagai bekal mereka
sebelum terjun ke dunia kerja dan
mempraktekkan teori yang sudah
mereka dapatkan dibangku
perkuliahan.

\section{Prosedur Kerja dan rencana Kegiatan}

Di lakukan dengan tiga tahap yaitu persiapan, pelaksanaan, dan pelaporan

1. Persiapan

a. Mempersipkan mitra sebagai peserta

b. Mempersiapkan bahan modul dan materi pelatihan yang disampaikan

2. Pelaksanaan

a. Sosialisasi terhadap rencana program pengabdian dan koordinasi mengenai evaluasi rencana program

b. penyuluhan mengenai penggunaan alat jangkar

c. Pelatihan mengenai administrasi

d. Pelatihan dan praktek mengenai aplikasi website

e. Pendampingan

f. Monitoring dan evalusai mengenai kegiatan ini dengan cara interview, diskusi, dan observasi terjadwal

3. Pelaporan

a. Merupakan evaluasi akhir terhadap dampak program pengabdian terhadap mitra yang diukur dari indikator capaian

b. Evaluasi capaian atas target luaran IbM menjadi penting sebagai evaluasi dan pelaporan kepada dikti. 


\section{HASIL DAN PEMBAHASAN}

Sudah umum diketahui bahwa di Indonesia, UMKM mempunyai peran yang strategis dalam menopang perekonomian nasional. Sesuai dengan data dari kemenkop dan UMKM bahwa pada akhir tahun 2012 sektor ini mampu menyerap tenaga kerja sebesar 97,16 persen..

Salah satu UMKM adalah tenun Troso. Tenun Troso merupakan kain hasil ATBM (alat tenun bukan mesin) yang berasal dari desa Troso Kec. Pecangaan Kab. Jepara Prop. Jawa Tengah. Tenun Troso sudah menjadi penopang utama ekonomi warga desa Troso. Bahkan sekarang ini sudah menyebar tidak hanya luar desa Troso tetapi juga luar kabupaten Jepara. Di samping itu, tenun Troso dapat dipakai dalam aktifitas sehari-hari baik formal ataupun non-formal.

Namun demikian kebanyakan pelaku UMKM umumnya, pelaku tenun Troso usaha ini dalam menjalankan usahanya masih mengandalkan keuletan dan kerja keras, belum mendapatkan sentuhan-sentuhan tehnologi dan tata kelola yang baik. Sehingga usaha ini memiliki tingkat kerentanan yang tinggi ketika dihadapkan pada adanya persaingan ekonomi yang terbuka secara global pada umumnya maupun regional (MEA) pada khususnya.

Setelah melakukan pendekatan kepada kedua mitra, tim menemukan permasalahan-permasalahan yang selama ini terjadi. Permasalahan tersebut terkait dengan manajemen, Produksi, dan pemasaran.

\section{Penyusunan Sistem Administrasi}

Selama ini, kedua mitra dalam menjalankan usahanya belum menerapkan tata kelola yang baik khususnya terkait dengan pencatatan melainkan masih menjalankan secara sederhana yaitu hanya melakukan pencatatan dari sisi pemasukan dan pengeluaran secara umum saja tanpa adanya pengelompokan atau perincian yang baik.

Setelah tim melakukan interview dengan mitra dan analisis situasi kerja, kemudian tim menyusun sistem administrasi yang cocok bagi kedua mitra. Sistem administrasi tersebut dapat dikelompokkan dalam 4 (empat) bagian yaitu laporan transaksi kas harian (keuangan), daftar biaya tenaga karyawan dan setoran barang (biaya dan barang), laporan persedian bahan baku (persediaan bahan baku), dan laporan laba rugi. 
Bagian pertama, Laporan transaksi kas harian. Bagian ini menggambarkan mengenai transaksi kas harian dari seluruh aktifitas usaha. Dalam laporan ini terdiri dari beberapa item yang disusun berjajar ke kanan yaitu mulai tanggal, bulan, tahun, Nama Akun, Nama, Nama Unit/Barang, Kuantitas, Jenis Satuan, Harga per Satuan, Jumlah, keterangan (pemasukan dan pengeluaran), sampai dengan total saldo. Dari catatan ini, pemilik dapat dengan mudah mengetahui posisi kas yang ada setiap saat dan rata-rata perputaran kas secara harian, mingguan, serta bulanan. Sehingga hal ini akan memudahkan bagi pemilik untuk memutuskan suatu planning dan action ekonomi yang penting dan cepat untuk diputuskan demi pengembangan usahanya.

Bagian kedua, daftar biaya tenaga karyawan dan setoran barang. Bagian ini secara umum dibagi menjadi dua sisi yaitu sisi biaya dan piutang. Sisi biaya terdiri dari beberapa item mulai dari tahun, bulan, tanggal, nomor, nama karyawan, nomor buku, keterangan, jumlah barang biaya per barang, jumlah, dan total biaya di bayar. Sedangkan sisi kanan merupakan sisi piutang. Yang dimaksud piutang disis adalah nilai barang keluar baik itu dijual sendiri dan dititipkan pada para tengkulak. Dari catatan ini akan diketahui berapa total biaya yang dikeluarkan/dibayarkan untuk memproduksi suatu produk tenun Troso. biaya produksi tenun Troso banyak dipengaruhi tingkat kerumitan motif, waktu, maupun bahan ataupun cara pewarnaannya. Semakin rumit motif yang dikerjakan maka semakin membutuhkan waktu yang lama pengerjaannya, semakin lama waktu yang dibutuhkan maka semakin mahal biaya yang keluarkan. Sebaliknya juga demikian, semakin mudah/sederhana motifnya maka semakin pendek waktu yang dibutuhkan dan semakin murah biaya yang dikeluarkan.

Sedangkan sisi kanan adalah piutang. Pada sisi ini terdiri dari debit, kredit, dan saldo. Pada bagian ini pemilik bisa mengetahui berapa berapa barang yang keluar dan berapa nilai barang tersebut. Jumlah saldo menunjukkan mengenai nilai barang yang keluar. Semakin banyak nilai saldo maka menggambarkan semakin banyak jumlah barang yang keluar atau kredit. Catatan bagia kedua ini secara umum menggambarkan mengenai berapa biaya yang dikeluarkan untuk suatu produk sesuai dengan motifnya dan berapa 
keungtungan yang diharapkan dari masing-masing motif produk tenun Troso.

Bagian ketiga, yaitu laporan persediaan bahan baku. Catatan ini ditulis berdasarkan bahan baku yang digunakan. Bahan baku yang dipergunakan terdiri dari banyak jenis misalnya Catton, Csm, Polyster. Masing-masing catatan terdiri dari tanggal, bulan, tahun, jenis/Nama, keterangan masuk dan keluar), persediaan akhir harga satuan, nilai barang. Catatan ini menginfokan tentang seberapa banyak persediaan bahan baku yang tersedia, sehingga pemilik bisa mengetahui juga jenis bahan baku yang mana yang perlu diperioritaskan pengadaannya. Selain itu juga bisa mengetahui seberapa banyak nilai dan jenis perputaran masing-masing bahan baku.

Bagian keempat, laporan laba rugi yaitu model catatan laba rugi pada umumnya yang terdiri dari pendapatan, harga pokok penjualan, laba kotor, beban lain, dan laba bersih.

\section{Peningkatan Produksi}

Salah satu langkah yang dilakukan tim untuk meningkatkan produktifitas para mitra adalah dengan penambahan mesin Jangkar pada ATBM. Perbedaan mesin jangkar dengan ATBM adalah terletak pada motif dan kecepatan yang dihasilkan. Motif pada yang ada pada Jangkar ditentukan oleh kartu yang digunakan. Kartu ini dicetak sesuai dengan motif yang diinginkan. Sedangkan pada ATBM, penenun harus menata satu persatu helai benang sehingga membentuk motif yang diinginkan. Adanya perbedaan dalam membentuk motif inilah yang juga berpengaruh terhadap produk yang dihasilkan para pekerja tiap minggu atau harinya. Semakin banyak produk yang dihasilkan semakin banyak juga penghasilan yang didapat para pekerja. Ataupun sebaliknya.

Perbedaan lain dari mesin jangkar adalah tahapan proses yang dilalui sampai menghasilkan produk kain tenun. Pada mesin jangkar rata-rata tahapan yang dilalui hanya 3 (tiga) tahapan, sedangkan tenun ATBM, tahapan yang dilalui $4-8$ tahapan. Sehingga bisa dikatakan produk mesin jangkar lebih cepat dan lebih banyak dibanding ATBM. 
Gambar 1. Pemasangan Mesin Jangkar

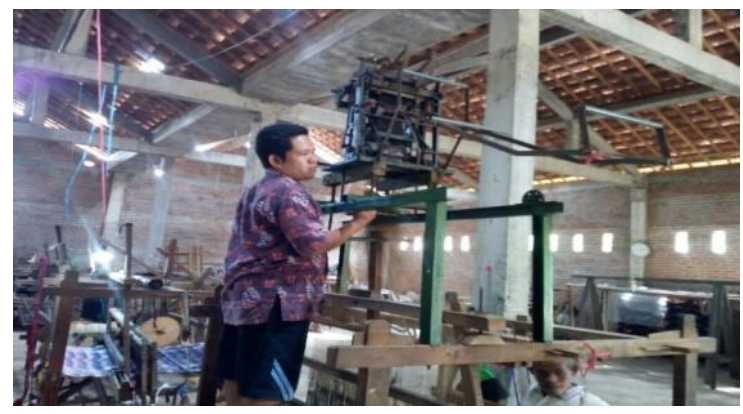

Gambar 2. Kartu Motif Jangkar

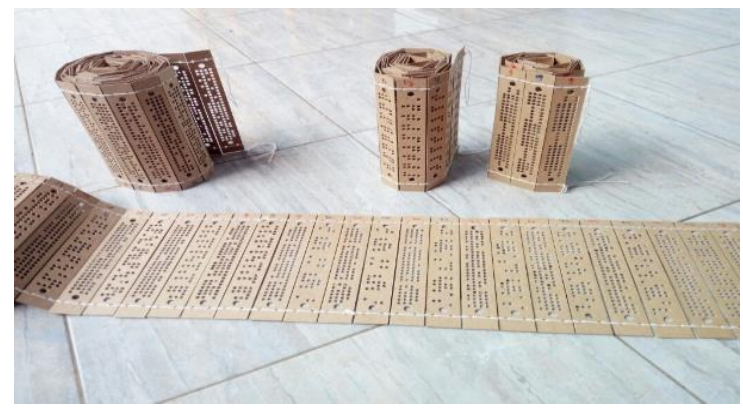

Pemberian Fasilitas Pemasaran on line

Di antara permasalahan yang dihadapi mitra adalah aspek pemasaran. Selama ini, mitra dalam menjual/memasarkan produknya selain dijual sendiri, sebagian besar melalui para tengkulak yang ada di desa Troso. Karenanya, harga jualnya mengikuti kemampuan para tengkulak dalam mendistribusikan kain tenun Troso.

Langkah yang lakukan tim pengabdi adalah pemberian fasilitas pemasaran on line dalam bentuk webs. Sebelum pembuatan webs, terlebih dahulu tim melakukan intervieaw kepada para mitra untuk mengkomunikasikan nama dan konten yang ditampilkan dalam webs tersebut.

Dengan fasilitas ini, mitra memiliki peluang yang lebih baik dalam penjualan dan pemasaran produknya sendiri. Sehingga kondisi ini bisa menjadikan mitra selain tidak menggantungkan lagi pemasarannya, produk mitra juga memiliki peluang yang lebih baik untuk diminati (dibeli) oleh masyarakat. sebab dengan fasilitas ini, sepanjang ada jaringan internet seseorang bisa melihat, memilih sesuai dengan seleranya masing-masing. Sehingga produk tenun mitra memiliki peluang yang lebih baik dibanding kalau hanya mengandalkan para tengkulak. Dengan cara ini ruang dan waktu yang selama ini menghambat sedikit banyak juga sudah diminimalisir

\section{Kesimpulan dan Saran}

\section{Kesimpulan}

Sejauh pengamatan dan hasil evaluasi tim IbM tenun Aqila dan Lumintu untuk pemberdayaan UMKM bisa dilaksanakan dengan baik. Pengabdian ini bisa disimpulkan bahwa kegiatan ini memberikan manfaat yang besar kepada kedua mitra. Mitra dapat memanfaatkan dan mengimplementasikan programprogram yang telah disampaikan. Manfaat tersebut diantaranya 1). Mitra 
dapat memanaj usahanya lebih baik. 2). Mitra memiliki produk dan motif yang lebih banyak dan lebih cepat lagi sehingga bisa melayani pembeli dengan lebih baik. 3). Mitra bisa memasarkan produknya lebih leluasa dan memiliki peluang yang lebih baik.

\section{Saran}

Saran yang bisa tim berikan kepada mitra adalah apa yang selama ini sudah tim sampaikan hendaknya bisa dijaga dan kelola dengan baik, tidak hanya pada waktu pendampingan saja, melainkan harus terus menerus sehingga memberikan manfaat yang berkelanjutan.

Bagi Uninsu Jepara bisa melajutkan pendampingan kepada masyarakat dalam bentuk kegiatan yang lain seperti KKN dan lainnya, sehingga pemberdayaan masyarakat ini bisa berkelanjutan.

\section{DAFTAR PUSTAKA}

Jumingan dan Rosita,2012,“Analisis Manfaat Informasi Akuntansi Pada UKM diWilayah Sukoharjo"GRADUASI Vol.8, 36-46

Nugrahani, D., S., 2011,"ECommerceUntuk Pemasaran Produk UsahaKecil dan Menengah" SEGMEN Jurnal Manajemen dan Bisnis, No.1, 116

Rahmana,A.,Iriani,Y.,Oktarina,R. 2012,"Strategi Pengembangan Usaha Kecil Menengah Sektor Industri Pengolahan'Jurnal TeknikIndustri, Vol.13, No. 1, 14-21 